\title{
AN ASSESSMENT OF LAND SUITABILITY FOR RICE CULTIVATION IN DOBI, GWAGWALADA AREA COUNCIL, FCT - NIGERIA
}

\author{
*AONDOAKAA, S.C. and AGBAKWURU, P.C. \\ http://dx.doi.org/10.4314/ejesm.v5i4.S2
}

Received 1st August 2012; accepted 8th September 2012

\begin{abstract}
This study examined the suitability of the soil in Dobi, Gwagwalada Area Council, FCT, Nigeria for rice cultivation. Soil samples were collected from the plot using systematic sampling procedure, at two standard depths of $0-15 \mathrm{~cm}$ (top soil) and $16-30 \mathrm{~cm}$ (sub soil). Standard procedures as applied to tropical soils were followed in analyzing the soil samples while the data obtained were statistically analysed. Results obtained were compared with the standard land quality requirements for rice cultivation in Southern Guinea Savannah. The soil parameters varied considerably but in general it was observed that, the high $\mathrm{pH}(6.73$ for top soil and 6.74 for subsoil as against the normal range of 3.1-5.3) is not favourable for rice cultivation. The level of organic carbon (0.89 for topsoil and 0.81 for subsoil), total nitrogen (0.05 both for top and subsoil) available phosphorus (13.35 for topsoil and13.00 for subsoil) cation exchange capacity (7.14 for topsoil and 6.99 for subsoil) in the soil is favourable for cultivation of rice. Furthermore, the calcium content (3.14 for topsoil and 3.01 for subsoil) in the soil is high which can be traced to the high soil $\mathrm{pH}$ which limits plant growth. Similarly, the magnesium level(2.06 for topsoil and 2.02 for subsoil) is high and as a base element, it limits rice yield. A parameter is considred high based on Olaleye, et al (2002)'s suitability evaluation for rice cultivation in Nigeria. The study recommended that for sustaining future agricultural productivity, there is need for detailed suitability assessment and land evaluation, also, a high dosage of NKP fertilizer application is encouraged and that salt free irrigation water can be applied to leach down the level of soil $\mathrm{pH}$ which will benefit both government and farmers for sustainable agricultural productivity.
\end{abstract}

Keywords: Rice, Land, Assessment, Suitability, Dobi, Cultivation.

\section{Introduction}

The Federal Capital Territory Abuja is one of the fastest growing areas in Nigeria due to its political status as the nation's capital city as well as its geographical location. As a result, this has led to a large and steady influx of people from all over the nation. Hence, the emergence as well as growth of settlements in the territory without considerable increase in food production.

Development in settlements and growth in population have been increasing the human demand for land as well as increase in the demand for food crops like rice, maize among others.

In recent years, the price for grains (especially rice) has increased with the cost of cultivation and production (Balogun, 2001). Sadly, in terms of area and production rice is one of the less important grains crops grown in the FCT. But in terms of economic importance, it is one of the most important crops. It is widely regarded as a superior food, which until recently was mainly consumed by city dwellers and middle and higher income earners (Dawam, 2000).

In an attempt to improve agricultural production, many agricultural development projects have been established like Fadama I, II and III sponsored by the world Bank in Nigeria. This makes it necessary to carry out strategies to improve food production. It is in this direction that a land suitability study is relevant. De Delta (1981) maintained that land/soil data should be made available and understandable to the users by providing interpretative ratings for specific land uses. The land qualities and land use requirements should be matched to enable farmers maximize out put in agricultural production by 
identifying the land qualities and the requirements for various land for effective management.

Olaleye (2001) identified Nitrogen, Phosphorus, Pottasium, Calcium, Magnesium and Manganese as important elements in rice production. Thus, the land suitability studies assist in identifying soils for optimum yields of some crops. In the same direction, FAO (1978) also had land classifications to identify areas suitable for some crops' cultivation.

Therefore, information is needed on soil qualities and conditions of the area, as well as the fertility status of the soil, to ascertain the chemical properties of the soil for rice cultivation. The need for such information constitutes the problem of the research.

Information obtained from such research will help in formulating meaningful guidelines in ensuring the sustainability of agricultural practice as well as rice cultivation not only in Gwagwalada Area Council, but the FCT in general and entire savannah region. This study hence seeks to advance such an understanding using Dobi, Gwagwalada Area Council as a case study.

Development in settlements and growth in population have been increasing the human demand for land as well as increase in the demand for food crops like rice, maize among others. In response to this, so many land uses are evident in the area of which agricultural land use is one of most notable apart from residential. From field observation the crops grown in the area are millet, sorghum, groundnut and maize with very few rice farms compared to other cereal crops mentioned earlier.

Gwagwalada Area Council which is one of the oldest and fast growing town in the FCT has been affected by the fact that so many agricultural types are being developed to meet various growing food demand as a result of the growing population. But rice which is an important food crop appears to lagging behind. In this regard, Dobi, Gwagwalada Area
Council is used as a case study in this research work to find out if the study area is suitable for rice cultivation, the quantity produced, how sufficient is it for the inhabitants and the scale of cultivation.

Therefore, information is needed on chemical properties of soil to ascertain its suitability for rice cultivation. The need for such information constitutes the problem of the research interest.

Information obtained from such research will help in formulating meaningful guidelines in ensuring the sustainability of agricultural practice as well as rice cultivation not only in Gwagwalada Area Council, but the FCT in general and entire savannah region. This study hence seeks to advance such an understanding using Dobi, Gwagwalada Area Council as a case study.

The aim of the study is to assess the suitability of Dobi area in Gwagwalada Area Council of the Federal Capital Territory, Abuja for rice cultivation.

This aim could be achieved through the following objectives:

1. To identify the land quality requirement for rice cultivation (chemical properties).

2. To assess the land quality (fertility status) of Dobi, Gwagwalada Area Council in relation to rice cultivation.

\section{Study Area \\ Location and Relief}

Dobi, Gwagwalada Area Council of the FCT is found between Latitude $8^{\circ} 55^{\prime} \mathrm{N}$ and Longitude $7^{\circ} 00^{\prime} \mathrm{E}$. It covers a total land mass of $2,316 \mathrm{sq} \mathrm{km}$ out of the $8,000 \mathrm{sq} \mathrm{km}$ of the total FCT land mass. Gwagwalada is situated on Iku-Gurara plains; these are the most extensive of all the plains. They lie west of the Zuba hill at the North-west of the territory. The area consists mainly of monotonously flat land dissected by streams that barely have distinct channels (Figure 1). 


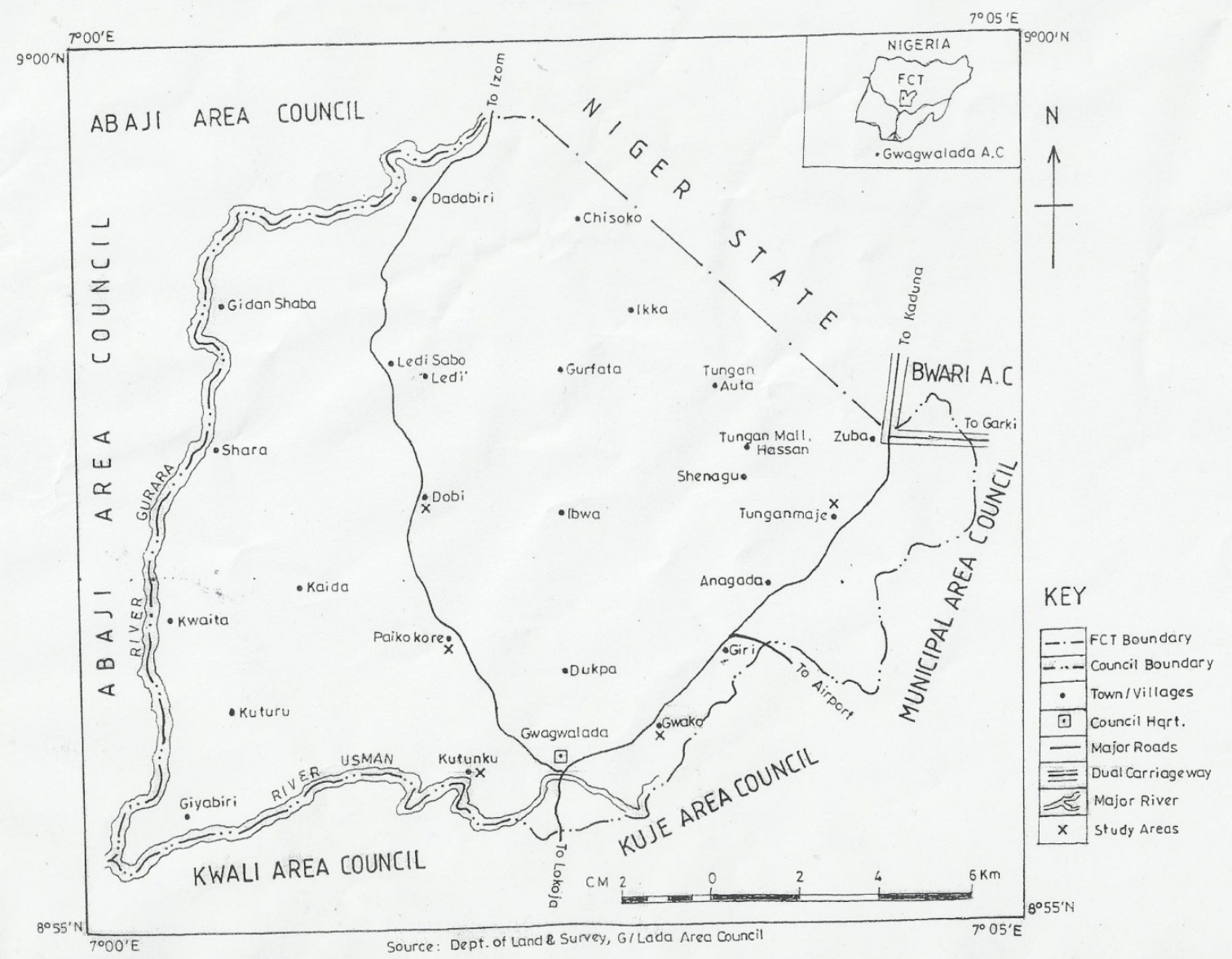

Figure 1 Map of Study Area

The elevation ranges between $150 \mathrm{~m}$ and $250 \mathrm{~m}$ with relative relief of between 50 and $200 \mathrm{~m}$. Swamps and flood plains are a prominent aspect of the landscape of these areas especially of the west towards the river Gurara Valley. The plains are connected to the Robo and Rubochi plains (to the South) by the flood plains of the river Gurara. Hill ranges run across the plains in a North-south alignment from Abuchi in the North-west to Kayodale in the South-west. The slopes are generally long and gentle with an average slope angle of $1.5^{\circ}$. (Dawam, 2000).

Gwagwa plains are located in the Northeast of the territory, south of the Bwari - Aso hills and North of the Agwai- Karu hills. The elevation ranges from $305 \mathrm{~m}$ in the west to about $610 \mathrm{~m}$ in the North-east. The Central and Southern parts of these plains are characterized by extensive uplands and numerous rock outcrops and inselbergs of various sizes which are scattered all over the plains. The entire plains are characterized by fairly extensive interfluves and hills with fairly convex crests, many of which are more than $2 \mathrm{~km}$ wide (Balogun, 2001). These plains, which provide the site of the municipal city, are drained by tributaries of the Usuman.

River Slope gradients ranges between $2^{\circ}$ to $6^{\circ}$ though steeper in areas which have witnessed stream incision on rock outcrops and inselbergs. Drainage texture is coarse and valley densities range between 1 and $2 \mathrm{~km}^{2}$.

So many land uses are evident in the area of which agricultural land use is one of most notable apart from residential. From field observation the crops grown in the area are millet, sorghum, groundnut and maize with 
very few rice farms compared to other cereal crops mentioned earlier.

Gwagwalada Area Council which is one of the oldest and fast growing towns in the FCT has been affected by the fact that so many agricultural types are being developed to meet various growing food demand as a result of the growing population. However, the cultivation of rice seems to be below expectation. In this regard, Dobi, Gwagwalada Area Council is used as a case study in this research work. More so, this research seeks to find out if the study area: Dobi, Gwagwalada Area Council is suitable for rice cultivation, the quantity produced, the scale of cultivation and how sufficient is it for the inhabitants.

\section{Soil Characteristics}

The soils in the study area are alluvial and clay silt which are generally moist and poorly drained almost all year round.

The soils of the upper slope occupy the highest points or the landscape as a result of which they are most freely and severely drained. The soils here and on the summits also differ in a number of ways with respect to their profiles. For example, the depth is shallower for the top soil than for the sub soil. They are predominantly reddish brown in the top layer and reddish in the subsoil layer of the summits (Balogun, 2001).

\section{Climate}

The region experiences two major seasons wet and dry season (Balogun, 2001). Change in temperature of as much as $17^{\circ} \mathrm{C}$ have been recorded between the highest and lowest temperature in a single say. During the rainy season the maximum temperature is lower due to dense cloud cover. Diurnal annual range is also much lower sometimes not more than $7^{0} \mathrm{C}$ in July and August. Its temperature ranges from $30.4^{\circ} \mathrm{C}$ and $35.1^{\circ} \mathrm{C}$. During the dry season, relative humidity falls in the afternoon (Abuja master plan, 2000).

The rainy season usually begins in March and ends in the middle of October in the North and early November in the South. Mean annual rainfall is about 1400. (Abuja master plan, 2000), as the result of it location on the windward side of the Jos Plateau leading to frequent rainfall and a noticeable increase in the mean annual total from the south to the North.

\section{Methodology}

The primary data for this research work was obtained through observation and collection of soil samples directly from the site of Dobi.

\section{Samples Collection}

The soil samples were collected at the onset of the rainy season. A measured quadrant of 20 by 20 meters (length and breadth) was used. The quadrant was divided into 16 equal grid squares; the length of the quadrant was divided into four parts of $5 \mathrm{~m}$ each for the length as well as the breadth. Soil samples were taken at the mid points of grid square at two standard depth of $0-15 \mathrm{~cm}$ (top soil) and $16-30 \mathrm{~cm}$ (sub soil). The site exists under uniform environmental characteristics (Climatic, Geomorphic and Vegetation). In order to reduce cost, the 25 soil samples for top soil and 25 subsoil samples were mixed randomly into a composite to get 7 soil samples each for top soil and sub soil respectively chosen for two main reasons. Firstly, the $0-15 \mathrm{~cm}$ represent the average plough layer in the area, while the $16-30 \mathrm{~cm}$ depth is the layer where clay particles accumulate following their elevation from the upper layer. Secondly, at these predetermined depth, we ensure comparability between the different samples selected.

The soil properties investigated were as follows: soil texture, organic carbon, total nitrogen, available phosphorus, exchangeable cation exchange capacity and soil PH. Standard procedures as applied to tropical soil (Kyuma et al, 1986) were followed in analyzing the soil samples.

\section{Data Analyses}

Descriptive statistics for the standard parameter (Average) for rice cultivation in Southern Guinea Savannah were compared with both the top and subsoils of Dobi, using T-Test with (SPSS 16.0) to test for significance difference. The reported value of the selected parameters of the standard for rice cultivation in Southern Guinea Savannah denoted as (X), the top soil as (Y) and sub soil as (Z) are shown in table 1 . 


\section{Results and Discussion}

\section{Chemical Properties:}

Soil pH

The Soil $\mathrm{pH}$ for both topsoil and subsoil of Dobi soils are significantly higher than the standard soil $\mathrm{pH}$ requirement for rice cultivation (Table 1) and this is indicated in the t-test assessment (Tables 3 and 4). In general, the topsoil and subsoil of Dobi soil is towards neutrality and soil of this type makes the absorption of nutrients for plant growth difficult because rice plant grows optimally under an acidic soil. Ponnamperuma (1977) further stated that the optimum conditions for nutrient uptake by rice from the soil solution consist of $\mathrm{pH}$ of about 6.6, between 0.01 0.12 (or $\mathrm{pH}$ between $0.2-2.0$ ) at $\mathrm{pH} 7.0$; a specific conductance of about $2 \mathrm{mmho} / \mathrm{cm}$ at $25^{\circ} \mathrm{C}$ is needed. The results found from Dobi (6.73 for top soil and 6.74 for subsoil) has been higher than Ponnamperuma's observation.

Table 1 Chemical Properties

\begin{tabular}{lccc}
\hline Parameter & $\begin{array}{c}\text { Land Quality } \\
\text { (Ranges) for Rice } \\
\text { Cultivation }\end{array}$ & $\begin{array}{c}\text { Topsoil Dobi, } \\
\text { Gwagwalada Area } \\
\text { Council }\end{array}$ & $\begin{array}{c}\text { Subsoil Dobi, } \\
\text { Gwagwalada Area } \\
\text { Council }\end{array}$ \\
\hline Soil pH & $3.1-5.3$ & 6.73 & 6.74 \\
Organic C $\%$ & $0.20-21.0$ & 0.89 & 0.81 \\
Total N\% & $0.10-0.02$ & 0.05 & 0.05 \\
Avail P (PPM) & $8.60-83.0$ & 13.35 & 13.00 \\
Ca (CmoL kg-1) & $2.70-0.85$ & 3.14 & 3.01 \\
Mg (CmoL kg-1) & $0.84-0.10$ & 2.06 & 2.02 \\
K/(CmoL kg-1) & $0.04-0.23$ & 0.24 & 0.25 \\
CEC (CmoL kg-1) & $2.12-11.39$ & 7.14 & 6.99 \\
\hline
\end{tabular}

Table 2 Top-Soil: (X \& Y)

T-test paired samples analysis of Top-soil of Dobi with the standard for Southern Guinea Savannah for Rice Cultivation.

\begin{tabular}{lccccccc}
\hline Parameter & $\begin{array}{c}\text { Number } \\
\text { of Pairs }\end{array}$ & $\begin{array}{c}\text { Mean } \\
\text { Difference }\end{array}$ & S.D. & t & df & $\begin{array}{c}\text { Significance (2 } \\
\text { tail) }\end{array}$ & Remark \\
\hline Soil pH & 2 & -2.530 & 1.556 & -2.300 & 1 & 0.261 & \\
Organic C\% & 2 & 1.860 & 3.606 & 0.729 & 1 & 0.599 & \\
Total N\% & 2 & -0.410 & 0.651 & -0.891 & 1 & 0.537 & \\
Avail P (PPM) & 2 & 3.910 & 62.013 & 0.892 & 1 & 0.536 & \\
Ca/Cmol kg-1 & 2 & -6.470 & 8.528 & -1.073 & 1 & 0.478 & \\
Mg (Cmol kg-1) & 2 & -2.130 & 1.287 & -2.341 & 1 & 0.257 & \\
K (Cmol-1) & 2 & -0.105 & 0.134 & -1.105 & 1 & 0.468 & \\
CEC (Cmol kg-1) & 2 & -0.385 & 6.555 & -0.083 & 1 & 0.947 & \\
\hline
\end{tabular}

$\begin{array}{lll}S . D & = & \text { Standard Deviation } \\ t & = & \text { The Calculated Value } \\ \text { d.f } & = & \text { Difference } \\ 95 \% & \text { Confidence Level }(0.05)\end{array}$


Table 3 Sub-Soil: (X \& Z)

T-test paired samples analysis of Sub-soil of Dobi with the standard for Southern Guinea Savannah for Rice Cultivation.

\begin{tabular}{lccccccc}
\hline Parameter & $\begin{array}{c}\text { Number } \\
\text { of Pairs }\end{array}$ & $\begin{array}{c}\text { Mean } \\
\text { Difference }\end{array}$ & S.D. & t & df & $\begin{array}{c}\text { Significance (2 } \\
\text { tail) }\end{array}$ & Remark \\
\hline Soil pH & 2 & -2.740 & 1.273 & -3.044 & 1 & 0.202 & \\
Organic C\% & 2 & 9.790 & 14.708 & 0.941 & 1 & 0.519 & \\
Total N\% & 2 & 0.010 & 0.057 & 0.250 & 1 & 0.844 & \\
Avail P (PPM) & 2 & 3.280 & 52.609 & 0.882 & 1 & 0.540 & \\
Ca/Cmol kg-1 & 2 & -1.235 & 1.308 & -1.335 & 1 & 0.409 & \\
Mg (Cmol kg-1) & 2 & -1.550 & 0.523 & -4.189 & 1 & 0.149 & \\
K (Cmol-1) & 2 & -0.115 & 0.134 & -1.211 & 1 & 0.440 & \\
CEC (Cmol kg-1) & 2 & -0.235 & 6.555 & -0.051 & 1 & 0.968 & \\
\hline
\end{tabular}

$\begin{array}{lll}\text { S.D } & = & \text { Standard Deviation } \\ t & = & \text { The Calculated Value } \\ \text { d.f } & = & \text { Difference } \\ 95 \% & \text { Confidence Level }(0.05)\end{array}$

\section{Organic Carbon $(C)$}

The level of organic carbon in both the top soil and subsoil in Dobi is significantly low compared to the standard organic carbon requirement for Rice Cultivation. But it falls within the range limits of the standard. The significant difference is indicated in the t-test $0.599,0.519$ (top soil and subsoil respectively). (Tables 2 and 3). But it should be clear here that this difference cannot limit the yield of rice, organic carbon are naturally supplied to soils through plants and animal decomposition and animal wastes over some period of time.

\section{Total Nitrogen (N)}

The level of the total Nitrogen in the topsoil and the subsoil falls within the range limit of the standard. The significance difference is indicated in the t-test 0.537 , 0.844 (Tables 2 and 3) Kunda et al (1996) postulates that Nitrogen as a macro-nutrient of rice, is needed in considerable quality for high yield. Therefore, based on Kunda, et al (1996), the nitrogen in the soil of the study area is not problematic.

\section{Available Phosphorus (P)}

The level of phosphorus in both the topsoil and subsoil of Dobi are significantly lower compared to the standard phosphorus requirement for rice cultivation13.35 (top soil), 13.00(subsoil) (Table 1). This is also evident in the t-test which shows a wide significance difference in the mean difference between both topsoil and subsoil and the standard phosphorus requirement. 0.536, 0.540 (Tables 2 and 3) This cannot be used to judge the level of phosphorous because Grant (1964) found that phosphorus is enhanced in a waterlogged soil and at the collection of the soil sample, the rainy season was evident to enhance phosphorus availability through the reduction of ferric oxides to $\mathrm{Fe}^{2+}$.

\section{Calcium (C)}

The level of calcium in both topsoil and subsoil of Dobi Area are significantly higher compared to the standard calcium requirement for rice cultivation. This can be traced to the nearness of the soil PH of the soil towards neutrality and possible salinity. The t-test also shows significant difference between both the topsoil and subsoil and the standard calcium requirement for rice cultivation. It is above the upper range limit of the standard.3.14, 3.01 (Table 1). High content of calcium might limit rice yield. As envisaged by both Razak et al (1962) that salinity and toxicity problems make rice cultivation difficult.

\section{Magnesium (Mg)}

The level of Magnesium in both topsoil and subsoil of Dobi are significantly higher than the standard soil magnesium requirements for rice cultivation 2.06, 2.02 (Table 1). This can be traced to the evident soil $\mathrm{pH}$ level in the test soil which tends towards neutrality and possible salinity. The t- 
test also indicates significant difference between the standard magnesium requirement for rice cultivation and both the top soil and subsoil 0.256, 0.149 (See Table 2 and 3). Magnesium of both the top and subsoil is above the upper range limit of standard requirement for rice. This might limit rice yield as it will add to the salinity of the soil. Too much of magnesium (base element) increases the salinity of the soil making it difficult for an optimum rice yield.

\section{Potassium (K)}

The potassium level of both the topsoil and the subsoil of Dobi are significantly higher than the standard potassium requirement for rice cultivation $0.24,0.25$ respectively (See table 1). Potassium is a macro-nutrient of rice needed in large quantity for the growth and better yield of rice (Bo and Thuan, 2001), the significance difference in ttest will not limit yield of rice in Dobi in any way.

\section{Cation Exchange Capacity (C.E.C)}

The level of the Cation Exchange Capacity in the subsoil of Dobi does not have any significance difference when compared to the standard Cation Exchange Capacity for rice cultivation but the topsoil have significance difference which is evident in the t-test $0.947,0.968$ respectively (Tables 2 and $3)$. Table 1 shows that the topsoil is above the standard C.E.C. requirement for rice cultivation but within the upper range limit while the subsoil and the standard range have almost the same mean. The Cation Exchange Capacity of the top and the subsoil of Dobi suit the cation exchange capacity of the standard requirement for rice cultivation because it can accommodate rice growth and yield.

Perveen, et al (2012) carried out a land suitability research at Haripur Upazila, a sub district of Thakurgaon district, North Western part of Bangladesh using Remote sensing and GIS techniques and found the $\mathrm{pH}$ level between 5.5 to 6.5 as a suitable range. This is comparable to our $\mathrm{pH}$ results of 6.73 for top soil and 6.74 for subsoil which is still suitable for rice.

Similarly, Kuria, et al (2012) who researched in Tana delta area of Kenya using
Remote sensing and GIS techniques, reported suitable areas for growing rice to have these characteristics: neutral to moderately alkaline, non sodic, imperfectly drained and usually the very dark gray clay. This description is still within the range of our research findings.

Furthermore, Samanta, et al (2011) carried out land suitability analysis for rice cultivation through GIS at Morobe province in the Papua New Guinea and reported the soil $\mathrm{pH}$ as 6.0 to 7.0 ; Nitrogen $(>0.5)$; Phosphorus $(>20 \mathrm{ppm})$; Potassium $(>20 \mathrm{ppm})$ to be rating 1 , that is highly suitable. Based on the supporting literature, the chemical parameters are suitable for rice cultivation in the study area and can be improved by management strategies.

\section{Conclusions}

On the basis of the result, the following conclusions are considered appropriate:

- Out of the eight chemical properties used as parameters for rice cultivation: Soil $\mathrm{PH}$, Organic Carbon, available phosphorus, total nitrogen, calcium, Magnesium, Potassium and cation Exchange capacity only five properties meet the standard land quality requirement for rice cultivation after comparison, which are: Organic Carbon, Total Nitrogen, Calcium, Soil PH, Cation Exchange Capacity (CEC).

- Using the FAO land suitability evaluation orders and classes of Dobi for rice cultivation, the criteria for land suitability measures the Dobi soil as moderately suitable as it satisfies five out of the eight chemical properties used as parameters, when compared to the standard land quality requirement for rice cultivation. More so, as limitation in the chemical properties of Dobi can be ameliorated, through management strategies.

\section{Recommendations}

In the light of the major conclusions of the study, the following recommendations are necessary:

- There is need for wide spread suitability assessment and land evaluation.

- Soil pH level of Dobi can be reduced by leaching with salt-free irrigation water because rice has a shallow root system only 
the topsoil $(0-20 \mathrm{~cm})$ requires leaching to reduce the level of salinity in the soil, electrical conductivity in the water should be $\left(0.05 \mathrm{dsm}^{-1}\right)$. This can also reduce the level of the base elements of calcium and magnesium to a favourable level.

- Applying sufficient NPK Fertilizers can also improve rice yield.

- Most times, both organic carbon and nitrogen are virtually supplied to the soil through plant and animal decomposition and animal waste, this can be incorporated into the soil through organic matter addition, organic farming, organic manure and agroforestry practice.

It will however, be worthwhile for monitoring, measurement, detection and assessment to be conducted on the extent to which incorporation of such measures could help in further improving the suitability of the land for rice cultivation. This will benefit both the government and the farmers and it will improve the production and supply of food for consumption and revenue generation among the increasing population which will bring about sustainable development in Agriculture especially in Rice Cultivation.

\section{References}

Balogun, O. (2001). The Federal Capital Territory of Nigeria: geography of its Development. University of Ibadan: Ibadan University Press.

Chandler, R.F., Jr. (1979). Rice in the Tropic: A Guide to the Development of National Programmes. London. Oxford University Press.

Dawam, P.D. (2000). The geography of Federal Capital Territory. Famous/Asanlu Publishers, Minna.

De Delta, S.K. (1981). Principles and Practices of Rice Production. New York: John Wiley and Sons Inc.

FAO (Food and Agriculture organization) (1978). Effects of compaction and puddling on soil physical properties and rice growth. Food and Agriculture Organization of the United Nations. pp. 68-73..

Grant, C. J. (1964). "Soil characteristics associated with the wet cultivation of rice In Indonesia".Indonesian Food Journal. 8 (2).
Kunda, D.K., Ladha, J.K. and Guzman, E. L. (1996). "Tillage depth influence on soil nitrogen distribution and availability in a rice lowland". Abstract of International Rice Research Institute No. 18pp. 102.

Kuria, D., Ngari, D. and Waithaka, E. (2011). Using Geographic Information Systems (GIS) to determine land suitability for rice crop growing in the Tana delta. Journal of Geography and Regional Planning. 4(9), 525532.

Available online at http://academicjournals.org/JGRP//pdf/2011/4t . Accessed on 11/8/2012

Kyuma, K., Kosaki, T. and Juo, A.S.R. (1986). "Evaluation of the fertility of the soils", in: A. S. R. Juo and J. A. Lowe (Eds). The wetlands and Rice in Sub-Saharan Africa. IITA, Ibadan, Nigeria, pp43-58.

Master plan for Abuja the New Federal

Capital of Nigeria (2000), Canadian

International development agency.

Olaleye, A.O., Ogunkunle, A.O., Sahrawt, K.L and Singh, B.N. (2001). "Characterization of some benchmark wetland soil in Nigeria for Rice Cultivation". Communication in Soil Science and Plant Annual (USA). 32(1\&2), 189-208.

Perveen, F., Nagasawa, R. Uddin, I. and Delowar,K.M. (2012), Crop- Land suitability Analysis using a Multicriteria Evaluation and GIS approach.

Available online at www.digitalearthisde.org/cms/upload/paper . Pp 1-8. Accessed on 11/8/2012.

Ponnamperuma, F.N. (1977). Physicalchemical properties of submerged soil in relation to soil fertility. International Rice Research Institute newsletter series No. 5.

Razak, M.N. and Roam Bhattachary (1962). Phosphate transformation in Rice Soil Indonesian Food Policy. 18: 12 - 32.

Samanta,S., Pal, B., and Pal, D.K (2011), Land suitability Analysis for rice cultivation based on Multi-criteria Decision approach through GIS. International Journal of Science and Emerging Technologies 2(1), 12-20

Available online at

ojs.excelintech.co.uk/index.php/IJSET/article/ download/270/141. Accessed on 11/8/2012. 